\title{
Job Marketable for Student with Disability: What We Should Know
}

\section{for Career Transition Programme}

\author{
D.O.I - 10.51201/12507 \\ https://doi.org/10.51201/Jusst12507 \\ Mohd Syazwan Zainal ${ }^{1}$, Muhammad Sofwan Mahmud ${ }^{1, *}$, Wan Ahmad Munsif Wan Pa 1 \\ ${ }^{1}$ Faculty of Education, Universiti Kebangsaan Malaysia, 43600, Selangor, Malaysia.
}

Copyright $\odot 2020$ by authors, all rights reserved. Authors agree that this article remains permanently open access under the terms of the Creative Commons Attribution License 4.0 International License

\begin{abstract}
People with disabilities face the greatest challenge of getting a job. This is because of thelow marketability skills of this group. Career transition programme (CTP) has been introduced to students with disabilities (SWDs) to prepare and train them for job market.Skills training in the field of employment is provided to SWDs in the implementation of CTP. However, it is still difficult for this group to get a job despite having good skills.A survey study was conducted to identify the marketability skills required in planning and implementing CTP in schools. Four teachers in a secondary school in Selangor who have implemented CTP were selected as study participants. The data from interview were recorded and analysed thematically. Through the findings of this study, itshows the four main marketability skills required by SWDs namelybasic academic skills, emotional management skills, communication skills and self-management skills in ensuring a successful CTP. The findings also demonstrate that it is important to ensure that SWDs are ready to enter the job market. It is also valuable to reflect the good results from CTP.
\end{abstract}

KeywordsCareer Transition Program(CTP), Students with Disabilities (SWDs), Marketability Skills.

\section{Introduction}

People with disabilities (PWDs) have been excluded from mainstream society; preventing them from living, learning, and working alongside people without disabilities (Eurostat, 2015; Shaw, Chan, \& McMahon, 2012). Because of this exclusion, people with disabilities have struggled to achieve personal goals such as obtaining competitive employment (Carter, Austin, \& Trainor, 2012; Kalargyrou, Trivellas, \& Sigala, 2020). It is suggested that disability has a bidirectional relationship to poverty of which the presence of a disability increases the likelihood of the individual living in poverty, while someone living in poverty is, in turn, more likely to acquire a disability (WHO, 2011). This relationship is due to a number of contextual factors such as limited access to education, healthcare, and suitable employment opportunities. Regardless, conservative estimates project that $15 \%$ of the world's population possess a disability (World Bank, 2020).Unfortunately, the number is likely higher due to poor reporting and identifying of individuals with disability.

Report by United Nations mentions the majority of PWDS live in poverty because they failed to get a place in employment. This is supported by the World Bank Report on 2010 which says that the disabled are $1 / 5$ of the poorest in the world. Of the total Malaysian population, there are 409,269 PWDs have registered with the Department of Welfare Malaysia until 2016 (JKM, 2016). Of the total number of PWDs registered, only $0.01 \%$ PWDs managed to get a job and placed in various employment sectors (JKM) which is far from the government target of which to achieve $1 \%$ of working people with disabilities. PWDs are still facing difficulties to get a job and this phenomenon is an issue that needs serious attention (Trezzini, Schuller, Schüpbach, \& Bickenbach, 2020).

Sustainable Development Goals (SDGs) were introduced to call on governments around the world to promote comprehensive employment opportunities to everyone including the PWDs. The goal of the SDGs is to guide the government towards its universal and holistic implementation where it is individual and inclusive, to achieve global development over the next 15 years. In addition to directly targeting employment, the SDGs also emphasize the need to guarantee the right of the students with disabilities (SWDs) to have equal access to education. The OKU Action Plan 2016-2022 by the Ministry of Women, Family and Community Malaysia has proven that there is an effort to provide employment opportunities to the PWDs. The core of the second strategy which is 'Empowering the Economy of the Disabled' focuses on the field of employment for the disabled where this policy encourages to open more employment opportunities.

\subsection{Career Transition Programme}

The early career interventions within school settings have shown to improve work outcomes of youth with disabilities (Harvey, 2002; Scholl \& Mooney, 2004)yet systematic and equitable career development service provision is lacking.The career transition programme (CTP) is an effort in providing initial training for students.CTP is defined as a combination of various activities based on the individual 
students' needs, their preferences and interests to bein line with the needs of the job market, including job development as a preparatory step to work after finishing school (Mohd Nasir, 2016). Therefore, CTP from school to work environment is conducted to train SWDs to acquire certain skills and gain work experience outside their learning environment (Alias, 2014). CTP is designed specifically for SWDs to enable them to practise and strengthen the skills needed to perform well in the real working world(Alias, 2014; Bernaldez, 2015). Through the concept described, CTP is an ongoing process that provides SWDs to the real world of working life involving various parties such as schools, parents and employers.

The objective of CTP from school to work environment is to train SWDs to acquire relevant skills and gain work experiences outside their learning environment (Alias, 2013). The placements at actual workplaces with general working skills needed would give them the opportunities to learn about teamwork, responsibilities, and work ethics (Lindstrom, Doren, \& Miesch, 2011). Therefore, CTP is planned to suit the students' capabilities so that they could continue the learning process at their workplace. Moreover, CTP is defined as a coordinated set of activities designed for specific students with learning disabilities that promotes the students' transition to workplace after being trained with the required working skills (Shogren \& Plotner, 2012). This programme is not only to train the students with work-related skills but also to prepare them with relevant and useful skills to function in the work environment. Once they have acquired the skills, the students would be placed in the workplace for a period of time. These experiences would be valuable to assist them to be independent after they have graduated from school. Thus, the work experience gained through CTP would lead to the opportunities to work, and also indirectly boost up the students' self-confidence to enter workforce in the future (Lindstrom et al., 2011)

CTP in Malaysia was implemented by special education teachers(Alias, 2013). The teachers would carefully select qualified SWDs to be trained in the programme. These students' academic skills were not only assessed by the teachers but also their social and emotional development. Therefore, several observations were done in the class and also outside the class to identify their abilities in coping with the demands of the work environment later. CTP activities are designed based on the students' needs, interests, and also their goals to be in the programme. The students were taught and prepared withnecessary career-related learning to gain work experience. CTP has also provided specific learning process and assistance in preparing the SWDs to adapt in the actual work environment. In return, the experiences are hoped to enable SWDs to initiate positive interaction and ultimately build good rapport with co-workers and supervisors. It is vital for the students' well-being in the work environment. It was not an easy task for the teachers to look for employers that would accept these trained students as interns at their premises. This is because most employers approached by the teachers were reluctant to accept an intern with learning disabilities. However, with the teachers' determination to prove that these students were capable to work, finally a place of internship for these SWDs to gain work experience was secured (Alias, 2013).

In Malaysia, the implementation of curriculum through CTP for SWDs is still unclear (Bari, Mohd Yasin, \& Mohd Yusof, 2013). Although Ministry of Education decided the policy in Malaysia Education Blueprint 2013-2025, but the implementation of CTP for PWDs is still vague. A studyproved that the challenges in SWDs career path are the implementation of their vocational education curriculum, collaborative interaction and career preparation (Trezzini et al., 2020). This shows that the current curriculum for SWDs in Malaysia has many weaknesses as it does not provide students with sufficient vocational skills, generic skills important in their careerand low employability skills(Bari et al., 2013).

\subsection{Student Development In Career Transition Programme}

Various perspectives need to be lookedinto regarding student development through career transition programmes. Through the Taxonomy Transition Program 2.0 model (Kohler \& Gothberg, 2016), this model focuses on the aspects of workability skills in the student development component. Job marketability skills refer to the general competencies required in performing a particular type and level of works such as communication skills, problem solving skills, teamwork skills and individual's interpersonal skills(Sheppard \& Unsworth, 2011). Their development is assessed based on their mastery of academic skills, life skills, social and emotional skills. These factors determine whether they are able to work and maintain the field of employment. For researchers who look into career issues for PWDs in Malaysia, it is agreed that career development for SWDs should be paid attention even at school level especially in education programmes that provide skills-training such as career transition programmes and others. Aliza through her research finds that PWDs faced difficulties in adapting to a new environment, have weakness in communication skills (including communication with employers, colleagues and customers as well as the difficulty in understanding the direction) and negative behavior in completing the assignment(Alias, 2014)

Besides, social cognitive career theory based on Bandura's social cognitive theory(Bandura, 1999)is one of the most influential new approaches in career development. Although social cognitive career theory was not specifically developed to explain the school-to-work transition process, it offers a useful perspective from which to understand and support this transition. Social cognitive career theory views work transition as a gradual process, which could begin in the elementary and middle school years with developmentally appropriate interventions that should 
continue throughout the school years and beyond a student's entry into the workplace, rather than be concentrated at the end of high school. The thrust is on lifelong career development, not just on one that ends with high school graduation and entry into workplace (Lent, Hackett, \& Brown, 1999).

\subsection{The Study Problem}

Unemployment of PWDs is due to failure in mastering workability skills that meet the needs of employers (Mohd Yasin \& Ibrahim, 2017). Lack in generic skills which are the important skills in working andlesser employability skills also contributes to this issue(Nasri, Hamzah, \& Udin, 2012). Other than that, moderate level of skill and self-esteem of SWDs contributes to the challenges in their career development. Looking at the above situations, these factors are all seen as a gap in the development of students which are supposed to be instilled through the CTP at the school level and subsequently the career realm. This is in line with the results from a study which explains that career success in the true context of PWDs is determined by the quality of education and training experience received before hopping into the career world(Mazzotti, Rowe, Cameto, Test, \& Morningstar, 2013).

In addition, SWDs were found to have less employability skills(Nasri et al., 2012). This is because the employability skills acquired by SWDs in vocational education are not necessarily able to fully meet the needs of employers (Alias, 2014). The lack of skills to meet the needs of the job market is then used as an excuse by employers to deny the opportunity for people with special needs to get a job (Nasri et al., 2012). This finding is supported by (Abdullah, Yasin, \& Abdullah, 2015; Domzal, Houtenville, \& Sharma, 2008) stated that employers reportedly were not interested in hiring the PWDs because they assumed that these groups would have low work skills. A study also revealed that lack of work skills is a major factor that causes PWDs to struggle in getting a place in the job market(Mazzotti et al., 2013). On the other hand, employers today are more concerned with the quality of employees in terms of technical skills of the field studied, academic achievement, and personal qualities of individuals (Shaharuddin Ahmad, Noraziah Ali, \& Mohd Fauzi Hamzah, 2011).

PWDs continue to face countless barriers to have access to employment. Research suggests that many of these youth exit high school without the skills, experiences, and supports necessary to successfully participate in work environments (Alias, 2013, 2014). Therefore, it is important that researchers and professionals who work with PWDs determine ways to facilitate the transition from high school to adulthood in order to uphold the social and economic rights of these individuals.

\subsection{Objective of Study}

Apart from work skills, this study was conducted to identify the marketability skills needed to be given attention to in the implementation of CTP in schools.

\section{Methodology}

This case study uses a qualitative approach. The qualitative approach is based on the assumption that, the meaning or reality of a phenomenon is socially constructed by the perpetrators involved in the phenomena studied. Every meaning or knowledge gained in qualitative studies is holistic, multi-dimensional and dynamic (Creswell \& Crewell, 2018). Qualitative approachshares a similar goal which they seek to arrive at an understanding of a particular phenomenon from the perspective of those experiencing it. Therefore, qualitative approach is chosen as the most appropriateto answer the objective of study(Creswell \& Crewell, 2018). This study was conducted in a secondary school located in the district of Hulu Langat. This school was chosen because of the implementation of CTP in this schooland after receiving a recommendation from the Hulu Langat District Education Office.Participants in this study are among the teachers involved in implementing CTP for SWDs. Semi-structured interview methods were conducted on study participants. To ensure the smooth progress of the interviews and the data collected to explain the objectives of the study, the interviews are conducted in Malay language. The interview protocol is built on the components of student development in the Transitional Taxonomy Program Model 2.0. (Kohler \& Gothberg, 2016)with marketability skills as a reference in constructing interview protocols.Among the questions asked to study participants are:

1. What skills do students need to ensure them getting a job?

2. What are the issues often raised by students involved in career transition programmes?

3. How this issue will affect the effectiveness of the career transition programme?

Each interview was conducted for almost 20 minutes after obtaining an agreement from the study participants. A total of four participants consisting a principal, a senior assistant teacher and two special education teachers. The information of the study participants is displayed in table 1 below:

Table 1: Demographic Information of Sample Participants

\begin{tabular}{ccc}
\hline Respondent & Sex & $\begin{array}{c}\text { Experience } \\
\text { of teaching }\end{array}$ \\
\hline A & Male & 10 years \\
B & Female & 27 years \\
C & Male & 20 years \\
D & Male & 13 years \\
\hline
\end{tabular}


The results of the interviews were then recorded andanalysed thematically. Thematic analysis is a basic method in data analysis where the data needs to be defined and clarified in more depth in qualitative research (Creswell \& Crewell, 2018)Thematic analysis shares the same aim of analytically examining narrative materials from life stories by breaking the text into relatively small units of content and submitting them to descriptive treatment (Vaismoradi, Turunen, \& Bondas, 2013).

\section{Findings and discussion}

Job marketability skills are one of the challenges that exist in the implementation of CTP. There are many opinions related to job marketability skills fromteachers' point of view. All of the teachers agreed that students who followed CTP have a very low level of work ability. This is a factor that can hinder the effectiveness of the CTP.The findings are categorized into four themes as seen in Table 2 below:

Table 2: Marketability Skills Needed To Be Given Attention to PWDs In The Implementation of CTP in Schools.

\begin{tabular}{|c|c|}
\hline Marketability skills & Subthemes \\
\hline Self-management skill & $\begin{array}{ll}\text { - } & \text { Being independent } \\
\text { - } & \text { Listen to instruction } \\
\text { - } & \text { Time management } \\
\text { - } & \text { Self-care } \\
\text { - } & \text { Cope in real situation }\end{array}$ \\
\hline Emotional skill & $\begin{array}{ll}\text { - } & \text { Very sensitive } \\
\text { - } & \text { Unstable emotion } \\
\text { - } & \text { Self-confidence }\end{array}$ \\
\hline Communication skill & $\begin{array}{l}\text { - Can communicate well } \\
\text { - Can get along well with } \\
\text { others } \\
\text { Have a good relationship } \\
\text { with others }\end{array}$ \\
\hline Basic academic skill & $\begin{array}{ll}\text { - } & \text { Long \& short term memory } \\
\text { - } & \text { Writing \& reading skill } \\
\text { - } & \text { Counting skill / numerical } \\
\text { skill }\end{array}$ \\
\hline
\end{tabular}

\subsection{Self-management Skill}

According torespondent A, job marketability skills are the skills needed by students to get a job. Among the skills is self-management skills which includebeing able to be independent, listen to instructions and manage time;

" the most important skill is self-management skills, if the student is not good at self-management, how can we send him/her to work... .. Then, the student also needs to be independent. It is because whenever he/she is at work, the student has to do everything by himself/herself. "

RespondentD's view related to job marketability skill is thathe is more concerned with those skills compared to students' academics level. According to him, if a student gets level 3 of Sijil Kemahiran Malaysian but the student does not master the marketability skills, it will result in rejection and will lessen their opportunities to work;

"If the student is good at presenting himself to the employer, then he will be hired. This is because only students who are presentable and have good social skillscan go far. For examples, if the student is a quiet person, does not associate with people, likes to be alone and has problem listening to instructions, the employer will not hire them. As a result, similarissue will arise..."

How the SWDs are getting along in the workplace is also viewed by third parties such as employers, colleagues and customers. SWDs need to be excellent inmanaging themselves in order to adapt to the work environment. It will certainlyhelp them to avoid feeling uncomfortable with the new environment.

"For me it is not solely the skills or academics that are evaluated, but also their self-management to cope withthe reality of situations at the workplace." Respondent $D$.

"Besides, another problem faced by students is to familiarise themselves to the work environment. Many students could not easily adapt in the new place especially when the third parties are involved." Respondent $C$.

"We don't want our students to feel uncomfortable and awkward when they get a job. What commonly happens is when they meet new people, engage in a new atmosphere, they would start to feel awkward. If they find it hard to fit in, they will slowly feel burdened and want to stop working. It's a pity if it continues to happen." Respondent B.

The findings of this study are supported by Aliza(Alias, 2013)who stated that most people with disabilities are not accepted in the workplace and the causal factors arethe inability to adapt in the workplace and to be independent. The examples of these responsibilities are positive peer relations (socialization) and concern for the welfare of others (Greenspan, Barenboim, \& Chandler, 1976; Iannotti, 1979). Students must be aware of inappropriate behaviors, accept responsibility for them, and be determined to substitute misbehaviors with more appropriate ones for adequate socialization (Bandura, 1999; Holland \& Collins, 2020). Recent studies illustrated that self-management strategies are critical for the development of social skills among students for a successful transition from youth to adulthood (Briesch \& Chafouleas, 2009). 


\subsection{Emotional management}

In addition, the important aspectthat needs to be taken into account in workability skills to ensure that CTP objectives are achieved in emotional management. Students from various categories such as students with autism, Down Syndrome and learning disabilities find it hard to accept instructions, very sensitive in terms of emotions as well as have low social skills. Students' erratic emotions are one of the challenges that teachers and parents have to face. As respondent B said;

"Unstable student emotions is a very challenging factor to manage. For example, the student may be doing well at school but can be difficult at work. He/she might not want to work and becomes rebellious."

Thus, emotional behaviours can easily change as the environment changes and the changes provide different consequences. (Abdullah et al., 2015; Mohd Yasin \& Ibrahim, 2017)stated that there is a list of abnormal shown by SWDs that are not accepted by society norms. A student with abnormal behaviour can also disturb and harm himself and others around him. Therefore, PWDs who master the skills of controlling emotions, controlling behaviour, good at socialising and confident to survive in the outside world when they finish school will get the benefit (Strömbäck, Fjellman-Wiklund, Keisu, Sturesson, \& Eskilsson, 2020).

"Students without behavioral problems, can control their emotions and consequently, will retain their job." Respondent $C$.

"Self-confidence, the ability to socialize and manage themselves are among the workability skills that will be evaluated by the employer." Respondent $B$.

As stated by (Mohd Nasir, 2016), SWDs should be trained with emotional control skills as well as their level of self-confidence should be formed to enable them to be independent and willing to work in community groups. This is because, these skills are important job marketability skills evaluated by employers if they want to apply for a job outside. Teachers can help to change students' behaviour by helping them reorganise the environment and plan a new social environment (Mohd Yasin \& Ibrahim, 2017). Therefore, teachers need to be smart in overcoming these challenges by diversifying techniques or teaching approaches. As respondent A said;

"With regard to emotions, social and self-confidence, we receive students who have various ailments every year, what we can do is onlyto reduce those problems using the right approaches. Teachers need to be smart to handle these students."

\subsection{Communication Skill}

Communication skill among SWDs is very important. Furthermore, these skills become a vital part of employment requirements. According to respondent $\mathrm{C}$, communication is a factor for a student to get employed;

"Students who have mastered communication skills, that is, can communicate well, will get a place in the job."

While for PWDs who have problems to communicate especially with colleagues will face difficulties to stay long in any job;

"The student will find it difficult to stay at work if he/she does not have adequate communication skills. The worst can happen is that the student will be fired by the employer and will result in having to change jobs." Respondent $D$.

Therefore, all teachers agreed that communication skill is an important element in workability skills. It is advantageous for SWDs who are able to communicate well because they can indirectly build good relationships with schoolmates or colleagues when they are hired(Lindsay, Cagliostro, Leck, \& Stinson, 2019);

"If the student is a quiet person who does not get along well, it is difficult for the student to build relationships with people around him, especially colleagues. If he feels that nobodywants to be close to him, then it has a higher possibility that he wants to stop working. To sum up, that stems from the lack of communication skills. "Respondent $C$.

"Students who can communicate well will get a place in the job or they will continue their studies at community colleges." Respondent $C$.

Therefore, emphasis on the application of communication skills should be given priority. The results of this study are in line with the findings byAb. Halimand friends [45] where among the most important employability skills are communication skills. Similarly, SWDsneedto be trained with communication skills, self-control skills as well as skills that cultivate high self-confidence to enable them to be independent and workforce ready (Zainal, Hanafi, Yassin, \& Tahar, 2019; Zainal \& Hashim, 2019).

\subsection{Basic Academic Skill}

Basic academic skills are closely related to cognitive skills because they involve an internal process of thinking. One of the learning skills is the strategy to improve memory either short-term or long-term memory since it involves thought processes. However for SWDS, they have problems in maintaining short-term and long-term memory as they often forget what the teacher teaches. It is as mentioned by respondent $\mathrm{B}$ :

"Short-term memory is also a problem for us during the teaching and learning process. We try our best to deliver the knowledge and messages but the students will easily forget what we teach. Even at work, they need to be constantly reminded of what their job is." 
Apart from that, students with long-term memory is one of the requirement in marketability skills and it is evaluated by employers.

"Among the skill emphasised is, having a long-term memory. This skill is important to be evaluated by employers when students apply for a job." Respondent $C$.

It supported by sayingPWDs have physical abilities that can be trained through vocational education to be used in certain occupations(Zainal \& Hashim, 2019). However, to improve mental abilities such as improving memory, teachers need to constantly repeat the learning content and improve learning strategies by including more creative elements and innovations to attract SWDs interests. It coincides with a study (Derapa \& Mohamed, 2018)which stated that teachers need to have high skills and are knowledgeable in order to help with SWDs learning problems in the teaching and learning process while at school. In addition,teachers need to be prepared in terms of knowledge and skills before implementing a programme to ensure the programme runs smoothly and the targeted goals are achieved(Kohler \& Gothberg, 2016; Zainal \& Hashim, 2019). As respondent A said:

"Every year we receive students who have various ailments, what we can do is only to reducethe problems using the right approaches. Teachers need to be smart in handling these students. ",

Therefore, teachers need to constantly equip themselves with a variety of knowledge. They need to attend a lot, workshops, courses, related training and find additional information related to transition programmes (Alias, 2014). In addition, basic skills such as writing, counting and reading skills are one of the factors of employer acceptance in any job.

"Students who have masteredwriting, counting and readingskills, will get a place in the job." Respondent $C$.

"Although working skills are more important than academics, but the students here should know the basicssuch as reading, counting and writing. If they are not competent enough, the employer will refuse to hire these students to work in the organisation. Another example is for food-chain restaurants, it is a risk for them to hire employees who do not know how to read and count. Especially if the students have memory problems, none might want to hire them." Respondent D.

\section{Conclusion}

Transition phases are potentially stressful periods for SWDs and their caregivers. Fortunately, there are many processes, supports, and accommodations that can be put in place to enable seamless transitions. By usingwell-researched frameworks such as the Taxonomy for Transition
Programming 2.0, educators and agencies can identify areas for improvement to provide better support for persons with special needs and their families.

This study aims to provide understanding and to become a guideline for teachers, parents, employers and the parties involved such as government bodies, external agencies and the community on the needs and importance of this transition programme. In addition, this study can also provide information on the elements that can affect the effectiveness of the CTP so that the parties involved in the implementation of this programme can improve the transition programme in the future. This is because, the transition programme should also be coordinated involving various groups in its programme planning such as teachers, families, school administrators, communities and network of agencies and communities.

If SWDs do not master all the elements in this marketability skills, the SWDs will not be able to work and the main objective of CTP will not be successfully achieved. Similarly, if SWDs are able to place themselves in the world of work, they will not be able to last long. Therefore, the application of these skills is not only to produce students who are skilled in vocational but also able to appear as responsible individuals, trustworthy and always strive to improve themselves.

\section{Acknowledgements}

This study was fully funded by FPEND Research Grant: GG-2019-060, Faculty of Education, Universiti Kebangsaan Malaysia. Acknowledgment are also addressed to all who have been participated in this study especially all the informants.

\section{References.}

Abdullah, N., Yasin, M. H. M., \& Abdullah, N. A. (2015). Implementation of the inter-agency collaboration in vocational education of students with learning disabilities towards preparation of career experience. Asian Social Science, 11(18), 183-192. https://doi.org/10.5539/ass.v11n18p183

Alias, A. (2013). The issues in implementing transition program for special needs students. Asian Social Science, $\quad 9(16 \quad$ SPL), $\quad 9-14$. https://doi.org/10.5539/ass.v9n16p9

Alias, A. (2014). Transition program: The challenges faced by special needs students in gaining work experience. International Education Studies, 7(13), 192-196. https://doi.org/10.5539/ies.v7n13p192

Bandura, A. (1999). Social cognitive theory: An agentic Albert Bandura. Asian Journal of Social Psychology, 21-41.

Bari, S., Mohd Yasin, M. H., \& Mohd Yusof, M. (2013). School-to-work for hearing impaired students. 
International Journal of Education and Research, 1(7), 1-12.

Bernaldez, S. B. (2015). Job internship of students in the transition program of Fourth Estate elementary school Special Education Center: An action research. Scholarly Journal of Education, 4(November), 57-71.

Briesch, A. M., \& Chafouleas, S. M. (2009). Review and Analysis of Literature on Self-Management Interventions to Promote Appropriate Classroom Behaviors (1988-2008). School Psychology Quarterly, 24(2), 106-118. https://doi.org/10.1037/a0016159

Carter, E. W., Austin, D., \& Trainor, A. A. (2012). Predictors of postschool employment outcomes for young adults with severe disabilities. Journal of Disability Policy Studies, 23(1), 50-63. https://doi.org/10.1177/1044207311414680

Creswell, J. W., \& Crewell, J. D. (2018). Fifth Edition Research Design. In Sage.

Derapa, N. F., \& Mohamed, S. (2018). Kesediaan Guru Pendidikan Khas dalam Melaksanakan Mata Pelajaran Asas Tanaman. Jurnal ORTOPEDAGOGIA, 4(1), $66-71$. https://doi.org/10.17977/um031v4i12018p066

Domzal, C., Houtenville, a, \& Sharma, R. (2008). Survey of employer perspectives on the employment of people with disabilities: technical report. (Prepared under contract to the Office of Disability and Employment Policy, U.S. Department of Labor). (November).

Eurostat. (2015). Disability statistics - poverty and income inequalities. Statistics Explained, (October 2019), ISSN 2443-8819. Retrieved from http://ec.europa.eu/eurostat/statistics-explained/index .php/Disability_statistics_-_poverty_and_income_ine qualities

Greenspan, S., Barenboim, C., \& Chandler, M. J. (1976). Empathy and pseudo-empathy: The affective judgments of first- and third-graders. Journal of Genetic Psychology, 129(1), 167-168. https://doi.org/10.1080/00221325.1976.10534012

Harvey, M. W. (2002). Comparison of Postsecondary Transitional Outcomes Between Students With and Without Disabilities by Secondary Vocational Education Participation: Findings from the National Education Longitudinal Study. Career Development for Exceptional Individuals, 25(2), 99-122. https://doi.org/10.1177/088572880202500202

Holland, P., \& Collins, A. M. (2020). Supporting and retaining employees with rheumatoid arthritis: the importance of workplace social support. International Journal of Human Resource Management, O(0), 1-22. https://doi.org/10.1080/09585192.2020.1737175

Iannotti, R. J. (1979). Prosocial behavior, perspective taking and empathy in preschool children.

JKM. (2016). Jabatan Kebajikan Malaysia. Laporan Statistik. Availablbe from http://www.jkm.gov.my/

Kalargyrou, V., Trivellas, P., \& Sigala, M. (2020). Guests' stereotyping and quality evaluations of service delivered by employees with disabilities: does service failure matter? Asia Pacific Journal of Tourism Research, 25(7), 735-752. https://doi.org/10.1080/10941665.2020.1769697

Kohler, P. D., \& Gothberg, J. E. (2016). Transitioning Children with Disabilities. Transitioning Children with Disabilities, (January), 0-12. https://doi.org/10.1007/978-94-6351-134-6

Lent, R. W., Hackett, G., \& Brown, S. D. (1999). A Social Cognitive View of School-to-Work Transition. Career Development Quarterly, 47(4), 297-311. https://doi.org/10.1002/j.2161-0045.1999.tb00739.x

Lindsay, S., Cagliostro, E., Leck, J., \& Stinson, J. (2019). Career aspirations and workplace expectations among youth with physical disabilities. Disability and Rehabilitation, $\quad 0(0), \quad 1-12$. https://doi.org/10.1080/09638288.2019.1671505

Lindstrom, L., Doren, B., \& Miesch, J. (2011). Waging a living: Career development and long-term employment outcomes for young adults with disabilities. Exceptional Children, 77(4), 423-434. https://doi.org/10.1177/001440291107700403

Mazzotti, V. L., Rowe, D. A., Cameto, R., Test, D. W., \& Morningstar, M. E. (2013). Identifying and Promoting Transition Evidence-Based Practices and Predictors of Success: A Position Paper of the Division on Career Development and Transition. Career Development for Exceptional Individuals, 36(3), 140-151. https://doi.org/10.1177/2165143413503365

Mohd Nasir, S. N. I. (2016). Pelaksanaan Program Transisi Kerjaya ( Ptk) Murid Berkeperluan Pendidikan Khas ( Mbpk) Masalah Pembelajaran ( Mp ) Siti Nor Idayu Binti Mohd Nassir. 49.

Mohd Yasin, M. H., \& Ibrahim, R. (2017). Career Transition Programme of Hearing Impairment Students. Asia Pacific Journal of Intellectual Disabilities, (May).

Nasri, M. S., Hamzah, R., \& Udin, A. (2012). Falsafah Pendidikan Kebangsaan Memperkasakan Peranan Pendidikan Teknik Vokasional Dan Pendidikan Khas.

Scholl, L., \& Mooney, M. (2004). Youth with Disabilities in Work-based Learning Programs: Factors that Influence Success Wisconsin's Youth Apprenticeship Program: Background. The Journal for Vocational Special Needs Education, 26(1), 4-16.

Shaharuddin Ahmad, Noraziah Ali, \& Mohd Fauzi Hamzah. (2011). Kebolehpasaran Graduan UKM: Satu Kajian Perbandingan Antara Graduan Disiplin Sains dengan Bukan Sains. Jurnal Personalia Pelajar, 14, 81-90. Retrieved from file:///D:/PHD/Proposal Tesis PHD_reka bentuk kejuruteraan/Artikel/Isu Kebolehpasaran Graduan.pdf

Shaw, L. R., Chan, F., \& McMahon, B. T. (2012). Intersectionality and disability harassment: The interactive effects of disability, race, age, and gender. Rehabilitation Counseling Bulletin, 55(2), 82-91. https://doi.org/10.1177/0034355211431167 
Sheppard, L., \& Unsworth, C. (2011). Developing skills in everyday activities and self-determination in adolescents with intellectual and developmental disabilities. Remedial and Special Education, 32(5), 393-405. https://doi.org/10.1177/0741932510362223

Shogren, K. A., \& Plotner, A. J. (2012). Transition planning for students with intellectual disability, autism, or other disabilities: Data from the national longitudinal transition study-2. Intellectual and Developmental Disabilities, $50(1)$ $16-30$. https://doi.org/10.1352/1934-9556-50.1.16

Strömbäck, M., Fjellman-Wiklund, A., Keisu, S., Sturesson, M., \& Eskilsson, T. (2020). Restoring confidence in return to work: A qualitative study of the experiences of persons with exhaustion disorder after a dialogue-based workplace intervention. PLoS ONE, $15(7 \quad$ July), 1-19. https://doi.org/10.1371/journal.pone.0234897

Trezzini, B., Schuller, V., Schüpbach, S., \& Bickenbach, J. (2020). Environmental barriers to and facilitators of labour market participation as experienced by disabled people living in Switzerland. Disability and Society, https://doi.org/10.1080/09687599.2020.1768053

Vaismoradi, M., Turunen, H., \& Bondas, T. (2013). Content analysis and thematic analysis: Implications for conducting a qualitative descriptive study. Nursing and Health Sciences, 15(3), 398-405. https://doi.org/10.1111/nhs. 12048

World Bank.(2020). Available from https://www.worldbank.org/en/topic/disability.

WHO.(2011) World Health Organization. World report on disability 2011. Available online from http://www.who.int/disabilities/world_report/2011/ en/.

Zainal, M. S., Hanafi, M., Yassin, M., \& Tahar, M. M. (2019). Transition Program in Malaysia: The Challenges for Students with Special Needs in the Workplace. 3(2), 32-35.

Zainal, M. S., \& Hashim, H. (2019). The Implementation of Transition Programme for Students with Learning Disabilities in Malaysia. Creative Education, 10(08), 1802-1812. https://doi.org/10.4236/ce.2019.108129 